\title{
User Acceptance Test of Static Flight Simulator Boeing 737-800 of Universiti Kuala Lumpur MIAT
}

\author{
Mohd Harridon ${ }^{1,2}$, Mohd Khir Harun ${ }^{1}$, Abdul Aziz Ahmad ${ }^{1}$, Zaiful Hasmi Mohd Hashim³, Khairul Dahri Mohd \\ Aris ${ }^{1}$, Baha Rudin Abdul Latif ${ }^{1}$, Muzaffar Wasi Zainal Ariffin'1, Azizihadi Yaakop ${ }^{1}$, Mohd Jalal Amran', \\ Mohamed Idrus Abd Moin ${ }^{1}$
}

\author{
${ }^{1}$ Universiti Kuala Lumpur Malaysian Institute of Aviation Technology \\ ${ }^{2}$ Malaysia Civil Defence Force $\quad{ }^{3}$ ZRST Aviation Training
}

DOI: 10.29322/IJSRP.11.11.2021.p11936

http://dx.doi.org/10.29322/IJSRP.11.11.2021.p11936

\begin{abstract}
The Static Simulator of Boeing 737-800 that was acquired by Universiti Kuala Lumpur Malaysian Institute of Aviation Technology (UniKL MIAT) had gone through comprehensive testing to ensure its fidelity. The components to be tested were identified through a methodology which dissected the simulator into 2 mainstream fields which were physical and software. The primary gist was to identify components to be tested with the real Boeing 737-800 in mind. In this paper, we had laid out the components that were identified to be tested and at this time of the writing these components were currently being tested.
\end{abstract}

Index Terms- User Acceptance Test, Static Flight Simulator, Boeing 737-800

\section{INTRODUCTION}

$\mathrm{B}$ oeing had introduced several variants of the Boeing 737 and Boeing had been successful in marketing the aircraft. The New Generations of Boeing 737 are fitted with state-of-the-art avionics and flight system. One of the New Generations of 737 is the Boeing 737-800 and UniKL MIAT had purchased this variant as its Static Simulator.

Olason and Norton had indicated that the Boeing 737 is robust in its design in terms of take-off and landing [1]. They stated that the inherent aerodynamic design of the aircraft allows the Boeing 737 to be this robust [1]. Thus our decision to acquire the static simulator of Boeing 737 was validated as the aircraft is widely used and popular among airlines. Harridon elucidated the methodology governing the Factory Acceptance Test of the static simulator and various components were laid to be tested [2]. For this exercise however, we decided to govern our User Acceptance Test based upon the fact that the product is already installed at our venue. The usage of Flight Simulator is highly recommended as it offers future engineers and technicians to fully train themselves in actual maintenance processes of the aircraft since the simulator mimics realistically the scenarios of the real aircraft.

According to White and Padfield, the usage of flight simulator allowed individuals to improve their proficiencies and develop and enhance their capabilities within certain period of time [3]. The simulator also gave opportunities to researcher and students to identify problems pertaining to flight or aircraft and gave avenues for them to rectify any predicaments [3].

This publication is licensed under Creative Commons Attribution CC BY.

http://dx.doi.org/10.29322/IJSRP.11.11.2021.p11936
It is imperative to verify the acquired flight simulator so that any bugs or unwanted anomalies be ironed out before it is finally and officially accepted by UniKL MIAT. Leung and Wong stated that User Acceptance Test (UAT) is a good way to evaluate whether the product that was received is in accordance to the specifications that was laid out during the purchase [4]. They professed that the specifications should be defined in depth in order to avoid any ambiguities [4].

A framework should also be developed for the UAT in order to actuate the UAT in a structured and orderly manner. Harridon indicated that a structured and orderly manner is the proper way of "doing things" as it minimizes the chance of certain entities being left out [5]. Our UAT is structured and this is shown in our methodology as shown in Figure 1. Derivation of our methodology was based also upon the heuristics of our team members that have in combination more than 40 years experiences in the Aviation Field.

The important and vital part of a Flight Simulator is the integration of the software and hardware where both of these are needed to be in synchronization with each other. For example, if the N1 and N2 of the engine of the aircraft rise up or down, the throttle quadrant should also physically move in accordance to the quantum of movement of N1 and N2. Baarspul mentioned that it is imperative to do acceptance test upon the hardware and software entities of a product and also to ensure both of them are in tandem with each other [6].

The Static Simulator of UniKL MIAT is physically big with certain dimensions. Thus before the acquisition of the simulator, the team had prepared a customized venue to physically host the simulator. This is vital to ensure the simulator could physically fit into the venue with leverages existed surrounding the simulator to ensure proper ventilation. Without proper ventilation, the physical components of the simulator would be susceptible to wear and tear due to the environment.

\section{LITERATURE REVIEW}

Simulation plays an important role as it could simulate certain conditions where thorough analyses could be actuated which mimics real life parameters. For example, Nowacki and Olejniczak had analyzed the exhaust emission of Boeing 737 Max where the primary parameter was the consumption of fuel [7]. This 
is in some sense could also be partially mimic by a Boeing 737 simulator. Hence this indicated the vital role that a simulator could play.

The static simulator could also be used to replay or reenact certain scenarios in order to aid aviation investigation. Harridon had actuated analyses of aviation incidents and the data from these incidents could be replayed back using simulators [8]. The simulator could give visual cues upon the reasons behind such incidents. Since Boeing 737 is the most popular aircraft, it's imperative that maintenance technicians and engineers have the best training tools to equip them with the necessary skills.

According to Senturk, Kavsaoglu, and Nikbay, the most important part of the maintenance of the aircraft is the resources [9]. Resources also entails human resources such as maintenance personnel. It's vital for maintenance personnel to be sufficiently skillful in the maintenance process and as pointed out earlier the static simulator, such as the one at UniKL MIAT, is the right avenue to train these maintenance personnel.

Allerton contented that Flight Simulator has an ingrained advantage of reducing cost of training [10]. By using real life aircraft, the organization or company has to burn vital fuel which is in contrast with the simulator where no real fuel is burned. This decrease cost and in the long run would decrease overhead. Allerton also stated that the usage of simulator would increase safety as personnel would have numerous latitudes to practice in the simulator before proceeding to the real-life aircraft [10].

In any User Acceptance Test, it's imperative to examine the fidelity of the equipment or tools and in our case its vital for us to examine the physical being of the simulator. Harridon mentioned that in any missions, such as Search and Rescue Mission, it's imperative for the tools used in such missions be in appropriate conditions [11]. This is similar to our simulator where it should be in appropriate condition before it is use for training or real-life simulation purposes.

The Static Simulator also presents an opportunity for academicians and researchers to actuate studies upon aviation personnel that work upon aircrafts. For example, technicians or pilots that work upon the cockpit of the aircraft would spend considerable hours in the cockpit and these personnel could be studied upon when they actuate similar chores in the simulator. Sensors or physical gauges could be strapped onto these personnel to measure their vital health signs when they are in the simulator. Harridon had performed such measurements upon aviation academicians and similar methodology could be used upon these personnel working in the simulator [12].

As stated earlier, the acceptance of the simulator needs to be structured so that the end user would be satisfied with the product. According to Otaduy and Diaz, the User Acceptance Test should involve both parties, the manufacturer and customer, where there should be constant engagement between the two to ensure the end product meets the desired need [13].

\section{MeTHODOLOGY}

Our User Acceptance Test is primarily sectioned off into 2 segments, which are the Physical and Software acceptances. This is shown in Figure 1.

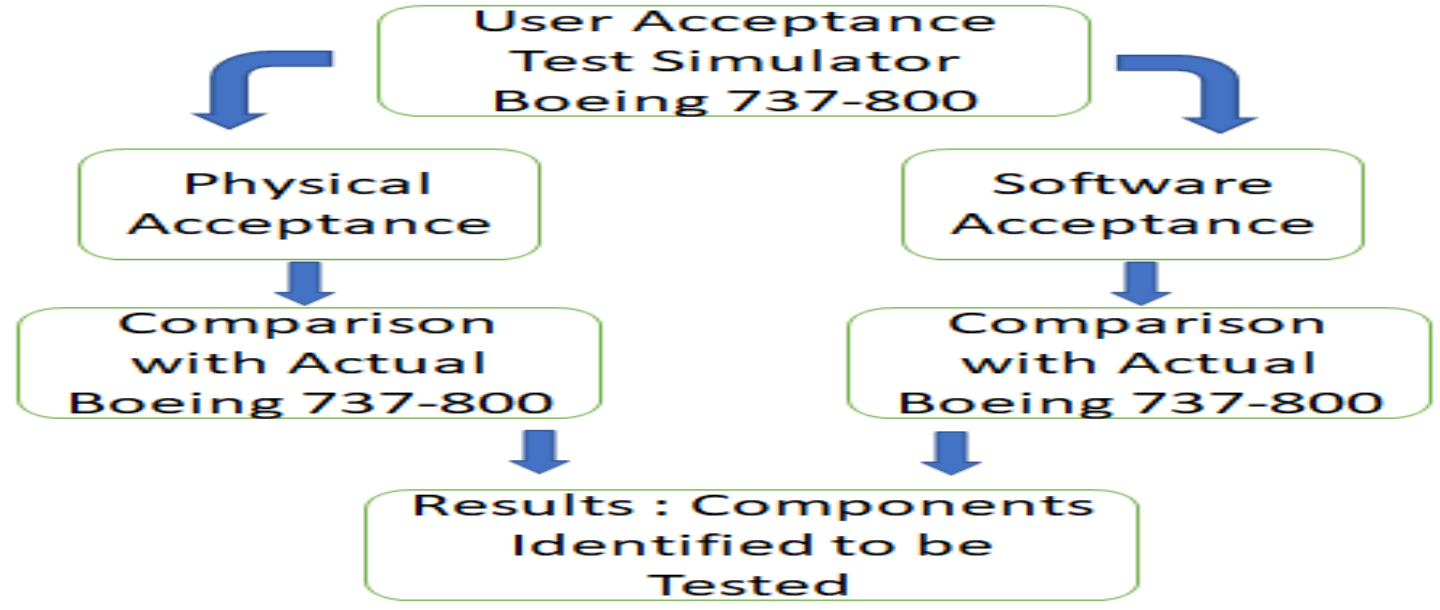

Figure 1. Our Methodology of User Acceptance Test

Performance, and others. For example, expert in the field of Navigation had rendered his opinion and expert in the area of

The Physical Acceptance consisted of comparison with actual physical entities of Boeing 737-800 where experience personnel that have extensive experiences in Boeing 737-800 were tasked to note differences or similarities. If there were differences, it was noted that calibrations are needed. These are shown in the Results Section of this paper.

The Software Acceptance also followed similar methodology and results are shown in the Results Section of this paper as well. We also sectioned the simulator into several entities as well based upon the experts we have at hand. These entities are : Engine, Avionics, Navigation, Instruments, Radios, Hydraulics, Flight
Engines had rendered his opinion as well. And this goes on for other areas.

\section{RESULTS}

The results of our User Acceptance Test are shown in Table 1. The results are non-exhaustive as the whole breadth of the simulator could not be presented in this paper due to confidentiality clause. Thus what are seen are small fragments of our User Acceptance Test. Also at this time of the writing, the User 
Acceptance Test is on-going and components that were tested and to be tested were noted in Table 1 .

Table 1. Results - Components Tested and to be Tested - Non Exhaustive List

\begin{tabular}{|c|c|c|c|c|c|}
\hline \multicolumn{6}{|c|}{ RESULTS : COMPONENTS IDENTIFIED } \\
\hline \multicolumn{3}{|c|}{ PHYSICAL } & \multicolumn{3}{|c|}{ SOFTWARE } \\
\hline COMPONENTS & STATUS & CALIBRATION & COMPONENTS & STATUS & CALIBRATION \\
\hline Throttle Quadrant & Tested & Need Further Calibration & N1 Indication & Tested & Need Further Calibration \\
\hline Stick Shaker & Tested & - & N2 Indication & Tested & Need Further Calibration \\
\hline $\begin{array}{l}\text { Fire Alarm Lights } \\
\text {-Engine 1 } \\
\text {-Engine } 2 \\
\text {-APU }\end{array}$ & $\begin{array}{l}\text { Tested } \\
\text { Tested } \\
\text { Tested }\end{array}$ & $\begin{array}{l}- \\
- \\
-\end{array}$ & Flaps Indication & Tested & Need Further Calibration \\
\hline Tiller & Tested & - & $\begin{array}{l}\text { Hot Start of Engine } \\
1\end{array}$ & Tested & Need Further Calibration \\
\hline Speed Brake & Tested & - & $\begin{array}{l}\text { Hot Start of Engine } \\
2\end{array}$ & $\begin{array}{ll}\text { To } & \text { be } \\
\text { Tested } & \\
\end{array}$ & \\
\hline Rudder Pedal & Tested & - & TCAS & Tested & - \\
\hline Flaps & Tested & - & AutoLand & Tested & - \\
\hline Control Wheel & Tested & - & Weather Radar & Tested & Need Further Calibration \\
\hline Brakes & Tested & - & $\begin{array}{ll}\text { Flight } & \text { Control } \\
\text { Indication } & \\
\end{array}$ & Tested & - \\
\hline Elevator Trim & Tested & Need Further Calibration & Various Weather & Tested & - \\
\hline $\begin{array}{l}\text { EHSI Knobs } \\
\text {-Zoom } \\
\text {-Legend }\end{array}$ & $\begin{array}{l}\text { Tested } \\
\text { Tested }\end{array}$ & - & $\begin{array}{l}\text { Engine Vibration } \\
\text { Indication } \\
\text {-Engine } 1 \\
\text {-Engine } 2 \\
\end{array}$ & $\begin{array}{l}\text { Tested } \\
\text { Tested }\end{array}$ & $\begin{array}{l}- \\
-\end{array}$ \\
\hline $\begin{array}{l}\text { Mode Control } \\
\text { Panel Knobs } \\
\text {-Heading Selector } \\
\text {-Altitude Selector } \\
\text {-Speed Selector } \\
\text {-Auto Throttle } \\
\text { Switch } \\
\text {-Vertical Rate }\end{array}$ & $\begin{array}{l}\text { Tested } \\
\text { Tested } \\
\text { Tested } \\
\text { Tested } \\
\\
\text { Tested }\end{array}$ & $\begin{array}{l}- \\
- \\
-\end{array}$ & $\begin{array}{l}\text { APU EGT } \\
\text { EGT } \\
\text {-Engine 1 } \\
\text {-Engine 2 } \\
\text { Fire Extinguishing } \\
\text { System } \\
\text {-Engine 1 } \\
\text {-APU } \\
\text {-Engine 2 }\end{array}$ & $\begin{array}{ll}\text { Tested } & \\
\text { Tested } & \\
\text { Tested } & \\
& \\
\text { Tested } & \\
\text { To } & \text { be } \\
\text { Tested } & \\
\text { To } & \text { be } \\
\text { Tested } & \\
\end{array}$ & $\begin{array}{l}- \\
- \\
-\end{array}$ \\
\hline $\begin{array}{l}\text { Communication } \\
\text { Radio Knobs }\end{array}$ & $\begin{array}{l}\text { To be } \\
\text { Tested }\end{array}$ & & Anti Ice System & \begin{tabular}{ll|} 
To & be \\
Tested & \\
\end{tabular} & \\
\hline $\begin{array}{l}\text { Navigation Radio } \\
\text { Knobs } \\
\text {-Captain Side } \\
-1^{\text {st }} \text { NAV Radio } \\
-2^{\text {nd }} \text { NAV Radio } \\
\text {-Co Pilot Side } \\
-1^{\text {st }} \text { NAV Radio } \\
-2^{\text {nd }} \text { NAV Radio }\end{array}$ & $\begin{array}{l}\text { Tested } \\
\text { Tested } \\
\\
\text { Tested } \\
\text { Tested }\end{array}$ & $\begin{array}{l}- \\
-\end{array}$ & $\begin{array}{l}\text { EADI } \\
\text {-Altitude } \\
\text {-Speed } \\
\text {-ILS } \\
\text {-Localizer Needle } \\
\text {-Glideslope Needle } \\
\text {-Retard Indicator } \\
\text {-Flare Indicator }\end{array}$ & $\begin{array}{l}\text { Tested } \\
\text { Tested } \\
\text { Tested } \\
\text { Tested } \\
\text { Tested } \\
\text { Tested } \\
\text { Tested }\end{array}$ & $\begin{array}{l}- \\
- \\
- \\
- \\
- \\
- \\
-\end{array}$ \\
\hline Rudder Trim Knob & $\begin{array}{l}\text { To be } \\
\text { Tested }\end{array}$ & & $\begin{array}{l}\text { EHSI } \\
\text {-Airport Indicator }\end{array}$ & Tested & - \\
\hline $\begin{array}{ll}\text { Aileron } & \text { Trim } \\
\text { Switch } & \end{array}$ & $\begin{array}{l}\text { To be } \\
\text { Tested }\end{array}$ & & $\begin{array}{l}\text {-Waypoint } \\
\text { Indicator } \\
\text {-Navigation Station } \\
\text { Indicator }\end{array}$ & $\begin{array}{l}\text { Tested } \\
\text { Tested }\end{array}$ & - \\
\hline
\end{tabular}




\section{DISCUSSION}

Peering Table 1, two main columns existed which are the Physical and Software. For both of these columns, the components of the simulator were listed and along with their statuses of "tested" or "to be tested". If there were discrepancies in the component in relation to the actual aircraft, the statement "need further calibration" was stated.

We had several components that are in need of calibration. For example, the Throttle Quadrant was staggered and was not in synchronization with each other (left and right throttle). This entails the need for calibration and we took note of it and this was conveyed to the manufacturer and the manufacturer had agreed to fix the predicament. We had also actuated numerous Flight Test upon the simulator and several entities were functioning as desired. For example, during one phase of the flight, we ascended and descended using the Auto Pilot and the aircraft climbed and dived as expected of a normal real Boeing 737-800. This was noted under Mode Control Panel Knobs where the Vertical Rate worked well.

It has to be noted during the Flight Test of the simulator the Auto Throttle was not functioning and this non-compliance was parlayed to the manufacturer and the manufacturer had fixed this via online. Needless to say, after the fix, the Auto Throttle performed well and it requires no further calibration as stated in Table 1.

During the Start Up of the engines of the Boeing 737-800 in the simulator, the N1 and N2 of both engines (engine 1 or 2) would show erroneous values but within a sporadic time frame. This intermittent problem posed a threat to the flow of the training of the students at our institute as we need a simulator that performs well and in a good consistent manner in lieu with the real life Boeing 737-800. This predicament is stated in Table 1 under the Software heading.

During another phase of our Flight Test, we had tested the EHSI and several labels or legends were populated upon the screen as per real life Boeing 737-800. For example, the airports and waypoints were in existence on the screen where their positions mimicked real life scenarios. Several other components under the Software heading were also tested and their need for calibration were denoted in Table 1.

\section{CONCLUSIONS}

The process of validating the simulator is an arduous and meticulous process where several aspects needed to be taken into account. The cost of the simulator is enormous and thus it's imperative that the return is substantial. To ensure the return is substantial, we need to ensure the end product has high fidelity and each and every entity of the simulator works well. Students would be using the simulator and we have the responsibility to give them a simulator that performs like the real life Boeing 737800. Our team had gone through discreetly the components of the simulator and this had been tabled in the Results Section of this paper. Our User Acceptance Test had identified several anomalies and those anomalies had been reported to the manufacturer for further action. Nevertheless our User Acceptance Test, with its methodology, had functioned as needed in order to qualify the simulator to be utilized by students of our institute.

\section{REFERENCES}

[1] Olason, M.L., and Norton, D.A., "Aerodynamic Design Philosophy of the Boeing 737", JA Aircraft, Volume 3, Number 6, November 1966, DOI : $10.2514 / 3.43771$

[2] Harridon, M., "Factory Acceptance Test of Static Flight Simulator Boeing 737 NG : Acquisition by Universiti Kuala Lumpur MIAT", International Journal of Scientific and Research Publications, Volume 11, Issue 3, March 2021, ISSN 2250-3153, DOI : 10.29322/IJSRP.11.03.2021.p11103

[3] White, M.D., and Padfield, G.D., "The Use of Flight Simulation for Research and Teaching in Academia", AIAA Atmospheric Flight Mechanics Conference and Exhibit, August 2006, DOI : 10.2514/6.2006-6493

[4] Leung, H., and Wong, P., "A Study of User Acceptance Tests", Software Quality Journal, 6, 137-149 (1997), DOI : 10.1023/A:1018503800709

[5] Harridon, M., "Conceptual Framework of Project Management for Space Industry Projects", International Journal of Scientific and Research Publications, Volume 11, Issue 6, June 2021, ISSN 2250-3153, DOI : 10.29322/IJSRP.11.06.2021.p11405

[6] Baarspul, M., "A Review of Flight Simulation Techniques", Progress in Aerospace Sciences, Volume 27, Issue 1, 1990, Pages 1-120, DOI : 10.1016/0376-0421(90)90006-6

[7] Nowacki, M., and Olejniczak, D., "Analysis of Boeing 737 Max 8 Flight, in Terms of the Exhaust Emission for the Selected Flight", Transportation Research Procedia, 35, 2018, 158-165, DOI : 10.1016/j.trpro.2018.12.033

[8] Harridon, M., "Incident Analyses of Helicopter Guimbal Cabri G2", International Journal of Scientific and Research Publications, Volume 10, Issue 12, December 2020, ISSN 2250-3153, DOI : 10.29322/IJSRP.10.12.2020.p10809

[9] Senturk, C., Kavsaoglu, M., and Nikbay, M., "Optimization of Aircraft Utilization by Reducing Scheduled Maintenance Downtime", $10^{\text {th }}$ AIAA Aviation Technology, Integration, and Operations Conference, 13-15 September 2010, Fort Worth, Texas, DOI : 10.2514/6.2010-9143

[10] Allerton, D., "The Impact of Flight Simulation in Aerospace - A UK Perspective", Aeronautical Journal New Series, 114(1162) : 747-756, DOI : $10.1017 /$ S0001924000004231

[11] Harridon, M., "Perception of Search and Rescue Crew of Malaysian Police Air Wing towards General Issues of Search and Rescue", International Journal of Scientific and Research Publications, Volume 10, Issue 10, October 2020, ISSN 2250-3153, DOI : 10.29322/IJSRP.10.10.2020.p10630

[12] Harridon, M., "Health Assessment of Academicians through Body Mass Index Evaluation and Relationship with Strain", International Journal of Scientific and Research Publications, Volume 10, Issue 11, November 2020 ISSN 2250-3153, DOI : 10.29322/IJSRP.10.11.2020.p10781

[13] Otaduy, I., and Diaz, O., "User Acceptance Testing for Agile Developed Web Based Applications : Empowering Customers through Wikis and Mind Maps", Journal of Systems and Software, Volume 133, Pages 212-229, November 2017, DOI : 10.1016/j.jss.2017.01.002

\section{AUTHORS}

First Author - Mohd Harridon, Universiti Kuala Lumpur Malaysian Institute of Aviation Technology, Malaysia Civil Defence Force, mdharridon@unikl.edu.my

Second Author - Mohd Khir Harun, Universiti Kuala Lumpur Malaysian Institute of Aviation Technology

Third Author - Abdul Aziz Ahmad, Universiti Kuala Lumpur Malaysian Institute of Aviation Technology

Fourth Author - Zaiful Hasmi Mohd Hashim, ZRST Aviation Training

Fifth Author - Khairul Dahri Mohd Aris, Universiti Kuala Lumpur Malaysian Institute of Aviation Technology

Sixth Author - Baha Rudin Abdul Latif, Universiti Kuala Lumpur Malaysian Institute of Aviation Technology 
Seventh Author - Muzaffar Wasi Zainal Ariffin, Universiti Kuala Lumpur Malaysian Institute of Aviation Technology Eight Author - Azizihadi Yaakop, Universiti Kuala Lumpur Malaysian Institute of Aviation Technology

Ninth Author - Mohd Jalal Amran, Universiti Kuala Lumpur Malaysian Institute of Aviation Technology
Tenth Author - Mohamed Idrus Abd Moin, Universiti Kuala Lumpur Malaysian Institute of Aviation Technology 